\title{
Multimedia technology and new pathways to learning
}

\author{
Nigel Paine \\ Scottish Council for Educational Technology
}

\section{Context}

Australia has a highly sophisticated and complex network of open and distance learning opportunities. These opportunities stretch from schoolbased learning through adult and community education programs into vocational education and training and higher education. Unique in the world, it is possible (although highly unlikely) for an individual to progress through school, non-advanced education and higher education without ever formally attending an institution. Technology has always played a part in this.

Most children around the world absorb images of Australian school children sitting by a rather crude valve-driven, two-way radio in crackly communication with a teacher in a larger population centre. It is an enduring and endearing image - so dominant that a large percentage of British children, for example, grow up convinced that this is an illustration of school education throughout Australia.

The dilemma is that as the courses become higher level, the technology involves drops proportionately. Most higher education uses the technology of the photocopier rather than the computer, although the fax for transmission of written work and return of comments is becoming ubiquitous. The fax machine took off in the Australian market faster than anywhere else in the world largely because Australians above any other nation were able to perceive the desirability of shortening distance with whatever means possible. 
There are indeed examples of wide and narrow band transmission of video images, computer-based learning at a distance, and general uses of technology. These are not always based in distance education faculties, and they still form a small proportion of total uptake.

\section{Conundrums}

The proportion of technological availability in off-campus learning is usually lower than on-campus, despite the acknowledged advantages and the bridging of distance that technology can create. This has led me to explore a number of conundrums:

1. No technological progress is possible without investment, but farsighted decisions on investment in kit only a few years ago look ludicrous now. Look at the British Open University's non-compatible PC; non-open systems networks; the UK BBC micro; and others. The need to rethink and upgrade as the technology evolves puts an acute burden on the providing institution but more so on the end user. The only piece of technology which has transformed education both onand off-campus and which will never become obsolete is the photocopier, and that is because it simply recreates and reproduces well-proven modes of information transmission (i.e. paper).

2. Equal and opposite blockers versus pressures: What are the blockers that prevent a sophisticated If infrastructure being set up for education and training?

Blockers:

- cash;

- vision;

- the numbers game;

- fear of premature obsolescence;

- lack of courseware and courseware development strategies.

Pressures:

Pressures which lead to developments:

- Pressure to make higher education more cost-effective; in other words, expand the number of students without expanding the cost in proportion.

- The need to make learning flexible, particularly in industry where the main business is not training.

- The need to engage individuals and make learning exciting and colourful.

- The drive towards competence where learners are being tested on what they can do rather than what they know, and where knowledge is underpinning rather than dominant.

- The need to manipulate ever-greater amounts of information in different formats to come up with a unique analysis and reading. 
3. Technological development is dominated by technologists, not educationists, and therefore there are plenty of technological solutions looking for problems and plenty of educational problems without obvious technological solutions.

4. Pressure of the market in terms of educational supply and demand can contradict the workings of the market in learning technologies. Both of these things mitigate against an effective program of action research where effectiveness can be quickly monitored and good practice passed on.

5. The economies of scale that large industrial conglomerates can bring to training technology investment are usually greater than the economies of scale which education institutions can bring to bear.

6. Hardware development usually outstrips software capability, and this in turn outstrips courseware development. To use the latest hardware can often mean inappropriate courseware.

7. The humdrum usually makes a greater impact than the spectacular showcase development. Technology is rarely humdrum.

\section{Needs of open and flexible learning}

In Scotland, for the first time since records were kept, the number of adults in higher education exceeds the numbers of 18-21 year olds. This is not as radical a change as it might appear, because many of the adults are on the lower level - higher level courses, and they are often part-time. Younger people are on the higher level - higher level courses and mostly full-time, but it is still a staggering statistic. The access pathways opened over the last 10 years pioneered by the Open University but now taken up by virtually every institution in further and higher education in an inordinate number of ways is definitely having an impact; but it delivers at a slower speed than the pressure to increase numbers into higher education and increase the skill base of the workforce. It is also still very difficult indeed for adults to participate in higher education, and often severe sacrifices (particularly financial) have to be made. There are still relatively few companies willing to invest in their workforce to the point where serious qualifications can result, although that is changing as well. 
This means that open and flexible learning are one of the many routes to access and ubiquitous in further education and adult basic education, although still relatively rare (British Open University excepted) in higher education. What we have to do is to break down the barriers between conventional delivery and other modes of delivery in order that the learner can choose one or more routes whenever it suits him or her throughout his or her learning career. This means there has to be a radical realignment in the way lecturers lectures and teachers teach in these sectors, and the skills of the open learning tutor and the distance educator recognised as part of the mainstream. We also have to invest consistently in sustaining that technological infrastructure which is just beginning to establish itself and be able to deliver meaningful education and training.

In a world where organisations are being taught to be more and more competitive, open and flexible learning require cooperation, continuity, and a rational division of resources. The prospectuses need to start with courses, move on to delivery methods, and offer the learner guidance through that matrix.

\section{Offerings of technology}

There is no real need now to produce masses of paper-based learning materials to deal with mixed mode delivery. An open learning centre in a TAFE college, or even a regional centre of a TAFE college, will have the technology to deliver the most sophisticated learning materials at a distance from a higher education establishment. There is nothing wrong with a long hard look at the appropriate medium for each piece of material, and some of the decisions will be based on using single camera videotape or even audiotape, as well as printed material and more sophisticated interactive learning materials.

As author languages become more sophisticated and the demands of linear progress less and less significant, the educator can take control and the programmer be relegated slightly so that realistic time allocations between the different media are possible.

Why is there any need to divide up the learning centres between the various sectors when every other part of the service industry is coming together to share resources under one roof?

\section{Desirability of partnership}

The better the education opportunities the further down the academic scale, the greater the pressure to come into higher education. It is not possible to expand higher education without building those access routes, and those access routes may often have to start in the community - the 
housing scheme, the area of a city, the rural community - even if they end on a university campus. And just like the ratio of committed viewers to general viewers in educational television, of every 100 viewers four will be prepared to write off for more details and one or two be prepared to take the program further and enter into some serious commitment to study. For every 100 people coming into a community education program, a small percentage coming through into higher education is not only acceptable, but desirable. The measure of access is not the number of converts, but the number of people who feel that they have been treated well, and feel themselves to be successful learners.

\section{Hopeful signs}

For every hopeful sign there is a bleak sign. The public expenditure problems and imminent cuts in Scotland and the UK are probably mirrored in Australia. However, there are shift in the commitment and focus of training in Australia, as illustrated by the recent publicity for some kind of federal operation of TAPE and the abolition of the binary line in higher education. In Scotland, further education colleges are becoming incorporated by statute in April 1993, the binary line in higher education was recently abolished, and new funding councils have been established throughout the UK. All these offer greater autonomy, improved flexibility, a real attempt to serve the learning needs of the narrower and wider drawn community.

Nevertheless, with the scurry for limited public funds and no real prospect of total commercial operation (or even desirability towards that) the vision will only be half completed.

The recent committee which I joined looking at educational technology and innovative learning in higher education in the UK, recommended the establishment of a learning board, the accreditation of good teachers in higher education, and the awarding of status to people who concentrated on the teaching as opposed to the research. The establishment of massive networks through higher education to allow exchange of materials and the wholesale development of core learning materials for higher education and basic skills areas, such as maths for engineering, communications for social science etc. The vision could be stillborn because there is simply not the cash to inject to set this up (however modest the total required) $£ 200 \mathrm{~m}$ against a higher education budget of billions of pounds.

Plans to set up the university in the Highlands and Islands as essentially an electronic university linking campuses big and small based on various existing institutions with a small administrative centre probably in Inverness, has met with widespread praise but every likelihood that the even smaller amount of money $(£ 250 \mathrm{~K}$ in the first year) will not be found. 
We have the technology but we have not really got the money, and that is very depressing and very demoralising where all other signs are auspicious.

\section{Learning and access to learning}

The key issue must be the building of effective learning in individuals. Learners must drive the new situation, and must be prepared to demand the highest standards of the institutions which accept them as their customers. There should not be anyone coming out of the higher education system who has not experienced the processes involved in an open learning environment, who has not been expected to be some degree as autonomous as the learner and who has not had to structure his or her learning at his or her own pace. The virtues of the committed open learner the contribution that they so evidently make to the world of work, should be seen as mandatory for all students, although the balance is negotiable; just as it is also inconceivable to imagine anyone emerging from a course of higher education having never used any kind of learning technology. Just as the theory indicates that neither of these things are likely at the current time, the practice speaks otherwise.

There are new pathways to learning; technology informs and helps structure those pathways but the essential focus is on the coherence, stability, and structure of the education system which all of this has to underpin.

Author: Nigel Paine is Chief Executive of the Scottish Council for Educational Technology. This paper was his Keynote address to the Biennial ASET EdTech'92 Conference, 1-3 October 1992 in Adelaide. http:// www.ascilite.org.au/aset-archives/confs/edtech92/edtech92_contents.html

Please cite as: Paine, N. (1992). Multimedia technology and new pathways to learning. Australian Journal of Educational Technology, 8(2), 99-104.

http: / / www.ascilite.org.au/ajet/ajet8/ paine.html 